\title{
Ny bevissthetsskala ved delirium
}

\author{
Et nytt verktøy for vurdering av bevissthetsnivå kan bedre diagnostikken av pasienter med delirium. Vi har over- \\ satt Observational Scale of Level of Arousal (OSLA) til norsk og vil ta den i bruk i klinisk praksis og forskning.
}

Delirium, «akutt forvirring», er en hyppig forekommende tilstand ved akutt somatisk sykdom, særlig hos eldre pasienter. Tilstanden er forbundet med dårlig prognose og økt belastning for pasient, pårørende og helsetjenesten. Delirium kjennetegnes av akutt endring i bevissthetsnivå, oppmerksomhet og kognisjon, gjerne ledsaget av persepsjonsforstyrrelser og endret søvn/ våkenhetsrytme. Tilstanden har en tendens til svingende forløp, skal ikke kunne forklares av en allerede kjent kognitiv lidelse (f.eks. demens) og skal være en direkte fysiologisk konsekvens av en annen medisinsk tilstand $(1,2)$. Delirium passerer ofte udiagnostisert hvis man baserer seg på subjektiv diagnostikk, klinisk intuisjon samt legers og sykepleieres individuelle erfaring. Særlig den hypoaktive varianten, med nedsatt psykomotorisk tempo, initiativløshet og somnolens, forveksles ofte med depresjon eller demens. Det mest brukte diagnostiske hjelpemidlet er Confusion Assessment Method (CAM). Imidlertid har det de siste årene kommet flere verktøy for diagnostikk og vurdering av pasienter med delirium.

\section{Observasjonsskala for bevissthetsnivå}

Observational Scale of Level of Arousal (OSLA) er en ny, kort skala for måling av bevissthetsnivået til pasienter med delirium (3). Den er utarbeidet av geriatere ved Universitetet i Edinburgh og er ment å supplere andre tilgjengelige bevissthetsskalaer, som for eksempel Glascow Coma Scale (GCS) eller Richmond Agitation-Sedation Scale (RASS). Disse fanger i mindre grad opp variasjonen og endringene man ser ved delirum.

Man fyller ut OSLA-skjemaet etter at man har sett til pasienten, og selve utfyllingen er rask å utføre (ca. ett minutt). Vurderingen baserer seg på observasjoner av pasienten $\mathrm{og}$ krever ikke at pasienten kan respondere verbalt. Skalaen dekker fire kliniske områder: Åpning av øynene, blikkontakt, kroppsstilling og bevegelse. Høyere poengsum indikerer et unormalt bevissthetsnivå. Total poengsum $(0-15)$ beregnes ved å legge sammen poengene fra hver kategori.

\section{Endring i bevissthetsnivået er assosiert med delirium}

Akutt oppstått endring i bevissthetsnivået, vurdert ved hjelp av OSLA, er sterkt assosiert med delirium og med alvorlighetsgrad av delirium (3). Påvisning av endret bevissthetsnivå kan bidra til økt diagnostisk oppmerksomhet og øke sannsynligheten for at deliriumdiagnosen stilles.

Vi har oversatt Observational Scale of Level of Arousal fra engelsk til norsk på følgende måte: Først oversatte én person teksten fra engelsk til norsk. Den norske teksten ble deretter tilbakeoversatt til engelsk av en tospråklig (engelsk og norsk) lege med klinisk erfaring innen geriatri og delirium. Til slutt ble den tilbakeoversatte engelske versjonen sammenholdt med originalversjonen, og svakheter ved den norske versjonen ble diskutert og endret. Vi vil i nær fremtid validere den norske versjonen av skalaen i forbindelse med en studie om legemiddelintervensjon ved delirium. Studien er planlagt å starte våren 2014 ved Geriatrisk avdeling, Oslo universitetssykehus. OSLA i norsk oversettelse er tilgjengelig på Norsk geriatrisk forenings internettsider (4).

\section{Bjørn Erik Neerland \\ bjorn.erik@neerland.net \\ Marc Ahmed \\ Leiv Otto Watne \\ Karen Roksund Hov \\ Torgeir Bruun Wyller}

Bjørn Erik Neerland (f. 1976) er lege i spesialisering $\mathrm{i}$ indremedisin og i geriatri. Han er klinisk stipendiat ved Geriatrisk avdeling, Universitetet i Oslo.

Forfatter har fylt ut ICMJE-skjemaet og oppgir ingen interessekonflikter.

Marc Ahmed (f. 1968) er spesialist i indremedisin og geriatri. Han er overlege ved Geriatrisk avdeling, Oslo universitetssykehus. Han jobbet i Storbritannia 1997-2007 innenfor både indremedisin og allmennmedisin.

Forfatter har fylt ut ICMJE-skjemaet og oppgir ingen interessekonflikter.
Leiv Otto Watne (f. 1977) er lege i spesialisering $\mathrm{i}$ indremedisin og i geriatri. Han er stipendiat ved Geriatrisk avdeling, Oslo universitetssykehus.

Forfatter har fylt ut ICMJE-skjemaet og oppgir ingen interessekonflikter.

Karen Roksund Hov (f. 1981) er lege i spesialisering i indremedisin og i geriatri. Hun er stipendiat ved Geriatrisk avdeling, Oslo universitetssykehus.

Forfatter har fylt ut ICMJE-skjemaet og oppgir ingen interessekonflikter.

Torgeir Bruun Wyller (f. 1960) er spesialist $i$ indremedisin og geriatri. Han er professor i geriatri ved Universitetet i Oslo og overlege ved Geriatrisk avdeling, Oslo universitetssykehus.

Forfatter har fylt ut ICMJE-skjemaet og oppgir følgende interessekonflikter: Han har mottatt forelesningshonorar fra AstraZeneca, Nycomed, Pfizer, Roche og EliLilly for emner knyttet til geriatri og medikamentell behandling av eldre, og mottatt royalty fra Gyldendal Akademisk for Geriatri - en medisinsk lærebok, som bl.a. omfatter delirium.

Litteratur

1. American Psychiatric Association. Diagnostic and statistical manual of mental disorders. 5. utg. Arlington, VA: American Psychiatric Association, 2013.

2. Neerland BE, Watne LO, Wyller TB. Delirium hos eldre pasienter. Tidsskr Nor Legeforen 2013; 133: $1596-600$

3. Tieges Z, McGrath A, Hall RJ et al. Abnormal level of arousal as a predictor of delirium and inattention: an exploratory study. Am J Geriatr Psychiatry 2013; $21: 1244-53$.

4. Norsk geriatrisk forening. Observasjonsskala for bevissthetsnivå. http://legeforeningen.no/ Fagmed/Norsk-geriatrisk-forening/Geriatrisktest--og-undervisningsmateriell/tester-ogregistreringsskjemaer/Observasjonsskala-forbevissthetsniva-OSLA (18.12.2013).

Mottatt 6.12. 2013, første revisjon innsendt 16.12. 2013, godkjent 18.12.2013. Redaktør: Matilde Risopatron Berg.

Publisert først på nett. Engelsk oversettelse på www.tidsskriftet.no 